Ssciendo Studia Anglica Posnaniensia 56s1 (2021): 361-385

doi: 10.2478/stap-2021-0002

\title{
THE MANUSCRIPTS OF THE MIDDLE ENGLISH LAY FOLKS'MASS BOOK IN CONTEXT
}

\author{
JEREMY J. SMITH ${ }^{1}$
}

\begin{abstract}
This paper, part of a long-term programme of research into the forms and functions of the vernacular in late medieval liturgical practice in England, offers a "cultural map" of the Middle English poem known as The Lay Folks' Mass Book (LFMB). Comparatively little research has been undertaken on LFMB since Simmons's edition of 1879. However, new developments in the study of manuscript-reception in particular regions of the Middle English-speaking areas of Britain, combined with greater understanding of the cultural dynamics of "manuscript miscellanies" and of medieval liturgical practice, allow us to reconstruct with greater certainty the contexts within which LFMB was copied and used. LFMB survives in nine late medieval copies, but each copy presented a distinct version of the text. This article brings together linguistic, codicological, liturgical, and textual information, showing in detail how the poem was repurposed for a range of different cultural functions. In geographical terms, it seems clear that the work circulated in Derbyshire/Nottinghamshire, in Yorkshire, and in Norfolk, and can thus be related to other texts circulating in those areas. Some versions are likely to have emerged in parochial settings, possibly owned by local priests. There is also evidence that the text could be deployed in monastic contexts, while other versions probably formed part of the reading of pious gentry. What emerges from a study of the codices in which copies of LFMB were transmitted is that a range of shaping sensibilities for these manuscripts may be distinguished; the authorial role in texts such as LFMB was balanced with that of their copyists and audiences. In the manuscripts containing LFMB creativity was negotiated within textually-transmitted communities of practice.
\end{abstract}

Keywords: Middle English; religious verse; manuscript studies; dialectology; textual criticism; liturgical practice; cultural mapping.

1 English Language \& Linguistics, University of Glasgow, Glasgow G12 8QQ, Scotland, UK. Jeremy.Smith@glasgow.ac.uk 


\section{On The Lay Folks’ Mass Book}

1.1. The Middle English poem now known as The Lay Folks' Mass Book (hence LFMB) survives in nine manuscript-witnesses dating from the late fourteenth to the late fifteenth centuries. The standard "modern" edition remains that carried out by Thomas Frederick Simmons, a late nineteenth-century clergyman (Simmons 1879; see also Jasper \& Smith 2019). Simmons's engagement with the text reflected not only his own liturgical expertise but also his interest in finding medieval exemplars for contemporary ritualist practice. His edition provides versions of the text from four manuscripts with readings from two others; the latter two were subsequently edited in full a few years later by researchers based in universities, reflecting the increasing professionalisation of philology (Gerould 1904; Bülbring 1905). Other copies have been identified since, and the current complete list, according to the New Index of Middle English Verse (= NIMEV, Boffey \& Edwards 2005: 234, item 3507), ${ }^{2}$ is as follows, with the first six sigla given below being those assigned by Simmons:
A = National Library of Scotland, Edinburgh, MS Advocates' 19.3.1, folios $57-58 \mathrm{v} * * *$
$\mathrm{B}=$ British Library, London, MS Royal 17.B.xvii, folios 3r-13r*
$\mathrm{C}=$ Corpus Christi College, Oxford, MS 155, folios 252v-268r*
$\mathrm{D}=$ University Library, Cambridge, MS Gg 5.31, folios $1 \mathrm{r}-5 \mathrm{v} * *$
$\mathrm{E}=$ Gonville and Caius College, Cambridge, MS 84/166 (Part II), pages $173-9 *$
$\mathrm{F}=$ Newnham College, Cambridge, MS 900.4 (olim Yates
Thompson), folios $104 \mathrm{v}-109 \mathrm{v}^{*}$
$\mathrm{G}=$ University Library, Cambridge, MS Ii.4.9, folios 55v-60r
(begins imperfectly)
$\mathrm{H}=$ University Library, Liverpool, MS F.4.9, folios 203v-207v
$\mathrm{I}=$ British Library, London, MS Additional 36523, folios 88r-93r

1.2. Despite these additional identifications, comparatively little research has been undertaken on LFMB since Simmons's day. Brief references in standard surveys (e.g., Raymo 1986; Duffy 2005; Pfaff 2009; Garrison 2017) do not take the

2 NIMEV is now linked to the online Digital Index of Middle English Verse (DIMEV), an ongoing resource-enhancement project developed by a team led by Linne Mooney (see https://www.dimev.net/index.html); DIMEV separates G from the other versions of LFMB. See, for the G-version, https://www.dimev.net/record.php?recID=2205; for the other versions, see https://www.dimev.net/record.php?recID=5537 (all URLs last consulted 18/06/2020).

3 *edited by Simmons 1879, accompanied by variant substantive readings from the A- and Dversions

** edited by Gerould 1904

*** edited by Bülbring 1905 
discussion of the work much further than did Simmons. However, new developments in the study of manuscript-reception in particular regions of the Middle English-speaking areas of Britain such as the appearance of the Linguistic Atlas of Late Mediaeval English (hence LALME = McIntosh et al 1986), combined - since LFMB does not survive as a stand-alone text - with greater understanding of the cultural dynamics of "manuscript miscellanies", allow us to reconstruct with greater certainty the contexts within which LFMB was copied and used. Important discussions of comparable miscellanies, with special reference to works of religious instruction, include (for instance) Margaret Connolly's study of devotional anthologies in fifteenth-century London (2003), and Ralph Hanna's research on the survival of the English works of Richard Rolle (e.g., 2007, 2010); both scholars have also approached matters in more general terms (e.g., Hanna 1996; Connolly 2011). And, as we shall see, recent research into medieval liturgical practice adds a distinct and important aspect to such work (see Harper, Barnwell \& Williamson 2016). But much detailed work remains to be done, from various disciplinary perspectives, to respond to the challenge set inter alia by Thorlac Turville-Petre almost forty years ago, viz. to set such works "much more securely and illuminatingly within [their] local context" (1983: 141). The following paper, part of a larger programme of study on the text, ${ }^{4}$ is a contribution to such "cultural mapping".

1.3. "LFMB" was Simmons's title, intended to align the text with other works which he - and like-minded colleagues, all clergymen - were involved in editing: The Lay Folks' Catechism (Simmons \& Nolloth 1901) and The Lay Folks' Prayer-book (Littlehales 1895-1897). All three works, as their Victorian titles suggest, were clearly seen by these antiquarian clergymen as being linked, and in

4 This programme of research is currently being undertaken with my colleague David Jasper; the current paper follows on from Jasper \& Smith 2019. Recent important responses to Turville-Petre's challenge include (inter alia) the essays collected in Scase 2007, and Connolly \& Mooney 2008.

$5 \quad$ For "cultural mapping" applied to medieval English texts, see especially Thompson 2008 and references there cited. LALME records a tenth version of LFMB, in Oxford, Bodleian Library, MS Ashmole 1286, analysed as Linguistic Profile (LP) 4276, placed in Northamptonshire. Unfortunately, this record seems to be an error; examination of the manuscript reveals it to be a miscellany of vernacular religious prose containing $A$ Contemplation of the Love of God, Poor Caitiff, The Seven Gifts of the Holy Ghost, Walter Hilton's translation of the pseudo-Bonaventuran Stimulus Amoris, and a small cluster of small theological treatises, including a partial English translation of the Somme Le Roi, and a prose English Praeparatio Eucharistiae. Several of these smaller texts (though not the Praeparatio) are cited in Jolliffe 1974. The manuscript is not cited as a witness for LFMB in the relevant entry in the New Index of Middle English Verse (Boffey \& Edwards 2005: 234, item 3507). The error in LALME probably derives from the appearance of Ashmole's Praeparatio as an Appendix to Simmons's edition of LFMB (1879: 122-127). I originally thought there was a confusion in LALME between this text and the I-version of LFMB, as cited in Jasper \& Smith 2019 , but that was a further confusion on my part, which I take this opportunity of correcting. 
their prefaces the editors made the connexions explicit; as already flagged, they saw the text as prefiguring their own carefully-nuanced nineteenth-century Anglican theological orientation. Later scholarship, however, has shown the three works to be rather distinct in purpose, although the titles these works have been given are not entirely misdirected: all three texts, it seems, were intended for use by pious folk - some lay, some religious - whose linguistic medium was English rather than Latin, part of the effervescence of innovative vernacular piety so characteristic of late medieval English religious culture (see Duffy 2005).

1.4. Thus, the Catechism was a manual of late medieval religious instruction prepared by the Benedictine monk John Gaytryge, at the behest of John Thoresby, archbishop of York, who had reaffirmed the importance of basic religious instruction for the "helpe of euery persoone pat penkip to be saued" (Connolly 2003: 170). The Catechism can be linked in contents to the Speculum Vitae, once ascribed to William of Nassington (see now Hanna 2009), as part of a distinctive Yorkshire religious culture of the late fourteenth century (the two texts survive together in Nottingham, University Library, MS WLC/LM/9; see Powell 1994; Greig 2018). It was repeatedly revised for different purposes, although the view that one of these versions was Lollard is no longer generally accepted (see Hudson 1985, although further study may bring about some revision of this view). The Prayer-book - which has not yet received as much attention as it deserves is one of the numerous primers that emerged in the late medieval period, designed to inform the prayer-life of the pious (see, e.g., Duffy 2006; but see still Bishop 1897). Whereas the Catechism and Prayer-book seem, even if rather loosely, to be translations of known Latin originals, there is uncertainty about LFMB's genesis. Simmons speculates about the author of the presumed lost original, "dam Ieremy" as he is referred to in the poem, who was a "deuowte mon \& a religyus" (LFMB, B-version, lines 18-19). Whoever "dam Ieremy" was - other versions, e.g., C, confuse him (ludicrously) with the better-known "seynte Ierome", the translator of the Vulgate - the author of LFMB emphasises that his work is a translation: "when I vpon po boke know hit/ In til englishe pus I draw hit" (3132). There is no evidence (pace Garrison 2017: 32) that the Middle English LFMB was composed much before the oldest (and, with E, fullest) surviving version, i.e., $\mathrm{B}$, which dates from the end of the fourteenth century.

1.5. The contents of LFMB can be summarised from the B-version, where the scribe alternates between text underlined in red ("rubricated") ink describing the celebrant's actions during the mass and directing the congregation's movements, and text without underlining used for prayers and meditations for the latter's use. It is thus a kind of vernacular libretto-cum-versified (alternative) prayer book, 
carefully aligned with the stages of the mass. ${ }^{6}$ After a brief reference to the importance of the mass, and how LFMB came to be composed, the poet describes how the priest, once vested, begins the celebration with his own confession; the congregation is then to make their own general confession, followed by the priest's absolution and the reading of the gospel, during which the laity is urged to think on the redeemer, saying a prayer for grace "in pi mynde/als pou may se wrytes here", repeated "oft in pi poght". Each stage in the mass is subsequently described, interspersed with prayers for the congregation to use: the recitation of the Apostles' ("peoples") Creed - the priest would be silently reciting the Nicene version - is followed by the offertory, and the priest's lavabo, during which the congregation is to think on its sins; the prayer to God to receive the sacrifice while the priest says his "priuey (i.e., secreta) prayers"; then summary headings for the core canon of the mass, as uttered by the celebrant: per omnia, sursum cordia, sanctus, and in excelsis (the congregation is to repeat these words with a "stille steuen" in the vernacular); a general prayer, followed by the sacring and elevation during which the congregation offer, alongside paternoster and credo, a prayer (one taken from Richard Rolle's The Form of Living is supplied, "in lettir/pou may chaunge hit for a bettir"); the Bidding Prayers, i.e., prayers for mercy, and for the souls of the dead; and finally the Lord's Prayer, the pax, a prayer for grace and (in case of sudden death; see Duffy 2005: 120) for the mass to stand in place of absolution, followed by the dismissal. At the end of the B-version, the congregation is told it is good to look from time to time at the robryk (i.e., 'rubric'), "to con [the prayers] withouten boke".

1.6. Examination of the remaining witnesses for LFMB, however, shows that like many vernacular works of religious instruction from the period it was regarded as a living text, open for revision: something Simmons already identified, and which Gerould in his later collations confirmed on the basis of shared presumed "non-original readings". The nearest to the B-version in form is E, which is of around the same length and has almost the same contents, although the scribe does not deploy the sophisticated paleographical distinction between descriptions of the priest's actions and instructions to the congregation, underlined in red ink, and prayer-material for the congregation's use is not so distinguished; there are therefore no references to the robryk. The E-scribe also replaces the word cros with a cross-sign, flagging a further slightly distinct approach to the visual pragmatics of the text.

6 The B-version was used as a guide in the important Experience of Worship in Late Medieval Cathedral and Parish Church project, funded by the UK's Arts and Humanities Research Council. See Harper, Barnwell \& Williamson 2016 for an account of the project; for the role of LFMB in this practice-based research, see especially p.238. This collection includes several important reconstructions of the participation of both laity and clergy in the mass, especially in Part IV, "Medieval liturgy and modern enactment". 
1.7. A second group identified by Simmons, i.e., the C-, D-, and F-versions, offers a shorter form of the text which reduces the material describing the priest's actions and the postures to be adopted by the congregation; this group also reduces formal elements potentially extraneous to the core elements of the mass (the vernacular versification of the Apostles' Creed, for instance, is omitted, as is the hymn-like "Ioy be vnto god in heuen", which occupies lines 119-148 in the B- and E-versions, and also the prayer for the mass to stand in place of absolution in case of sudden death). The F-version, like $\mathrm{B}$ in appearance if like $\mathrm{C}$ in contents, deploys rubrication to mark the "action" passages in the text, with black ink elsewhere; the C- and D-versions restrict themselves to coloured initials to mark sections. The F-version has in addition a shorter, modified opening, "[a]dapted", argues Simmons, "to the practice of smaller churches and chapels in England, where the priest vested before the people" (1879: 3); Eamon Duffy, however, indicates that the practice of vesting in front of the congregation was customary on weekdays (2005: 123). The F-version also includes some extra "link" lines (e.g., "Whanne confiteor thus is done/Pater noster folweth sone", lines 61-62), and also an expanded Latin version of the Ave.

1.8. The A-version belongs to this second group, but is a fragment only, with modified forms of the opening prayers, and various other minor changes in phraseology (e.g., it replaces C's "Ioy and louuynge", line 100, with "Ioy and blys"). The A-version's coverage equates to the first 128 lines of C, after the priest's lavabo, and ends with an additional couplet, suggesting that $\mathrm{A}$ was conceived of as being a poem of preparation for the canon of the mass - the introductory rites and the liturgy of the word ("the mass of the catechumens") rather than a comprehensive libretto covering the entire ritual:

$\mathrm{p}^{\mathrm{o}}$ holy goste pat is on hyght

Sende hus grace to leue ryght Amen

Explicit

1.9. Of the three versions unknown to Simmons, H belong to Simmons's second group, as does the I-version, although the latter deploys, fairly frequently, a modified phraseology; the impression left by $\mathrm{H}$ is of a free local reworking while sustaining an overall structure rather like that of $\mathrm{C}$. Unlike C, however, the I-version deploys red ink as a guide for readers, in the manner of $\mathrm{F}$, although the scribe retains C's opening. The G-version is a further departure from the models of B and C. Described in NIMEV as beginning imperfectly, closer examination shows $\mathrm{G}$ to be, rather, a much more radical revision representing yet another conception of the poem. The G-version removes the material of instruction that appears in rubricated form in B, and like the second group excludes the Apostles' Creed and the hymn of joy (interestingly, though, a vernacular Apostles' Creed appears elsewhere in the 
manuscript, as will be indicated below). However, $\mathrm{G}$ also cuts back considerably some of the later prayers, for instance following B's suggestion of "a bettir" usage by replacing the prayer at the elevation with a much shorter one:

$\mathbf{U}$ Elcom' lorde in forme of bred for me thov suffryd harde dede And thv bar' the crowne of thorne late me neuer be for lorn'

In sum, the G-version has been prepared with a distinct function, as a prayerresource rather than a full vernacular libretto.

1.10. Such modifications align with other practices in the production of vernacular religious texts in late medieval England. As Fiona Somerset has pointed out,

... late medieval religious writing in England more generally had magpie tendencies, prompted or facilitated by the circulation of loose leaves and unbound booklets from which material could readily be recopied or excerpted within other books (2013: 74).

Indeed, the B- and E-versions of LFMB both themselves display this habit; as already flagged, the levation-prayer "Loued be pou, kyng" (Simmons 1879: 40) is in origin a lyric that appeared earlier in Richard Rolle's guide for the recluse Margaret Kirkby, The Form of Living (see Woolf 1968: 380). Other examples of such practices abound. The early thirteenth-century Early Middle English Ancrene Riwle, for instance, was substantially reworked in the late fourteenth century, in a "modernised" form, in the well-known Vernon Manuscript (Oxford, Bodleian Library, MS Eng. poet. A.1), while two sections of the work, parts II and III, were reworked, in London, British Library, MS Royal 8 C.i, as a treatise on the five senses (for which see Baugh 1956; see also Smith 2020: chapter 3). Echoes of the Riwle seem to underlie works printed by Wynkyn de Worde at the end of the fifteenth century: The Treatise of Love and The Chastising of God's Children (see for instance Blake 1972: 174). John Mirk's Festial began life at the end of the fourteenth century as a sermon-cycle for parish use, but later appeared, in both manuscript and print, as a work for "private" devotion (see, e.g., Powell 1997, 2009; see also Smith 2013b, and references there cited). Lollard versions of older texts include "farced" versions of Richard Rolle's English Psalter Commentary (see Hudson 1985). Similar practices can be seen in the production of manuscripts of better-known literary works such as Langland's Piers Plowman or Chaucer's Canterbury Tales. Such works represent what Somerset has called "a textual culture of creative adaptation" (2013: 89). The reworking of LFMB is thus not alone. 
1.11. Such reworkings may be related to broader social developments: "the enhanced prestige of English, the interests of an increasingly literate laity in more advanced matters of theology than the rudiments of Christian behaviour, and dissatisfaction with the Church, expressed by orthodox and heterodox alike" (Spencer 1993: 14). Numerous examples demonstrating these trends may be identified, such as the appearance of "common profit" books designed for sharing vernacular works of devotion, such as John Colop's collection of religious (both orthodox and Lollard) texts, now Cambridge, University Library, MS Ff.6.31 (see Scase 1992). Works such as LFMB catered for the vitality of late medieval religious life celebrated by Duffy:

The fifteenth and early sixteenth centuries in England witnessed a period of massive catechetical enterprise on the part not only of the bishops and parochial clergy ... but also on the part of members of religious orders and private individuals (2005: 2-3).

If, as Duffy later argues, "liturgy, ritual, and traditional religious forms and imagery remained central to lay religion into the 1540s and beyond" (2005: 5), then the creation of works such as LFMB, which responded to a sustained demand for materials for pious reading and reflection, becomes explicable.

1.12. It is also important to recall that the production of LFMB took place in a world where texts were transmitted in bespoke fashion, in handwritten form and often in combination with other texts, and the manuscripts thus produced were the site of complex interaction between authors and scribes. As Malcolm Parkes famously put it, "Before the advent of printing a text left its author and fell among scribes" (1992: 70). Some of these scribes copied for others who had their own requirements for the books the scribes produced; others copied for themselves. Copying too required exemplars, and access to exemplars presented complex challenges. As a result, the witnesses for LFMB and texts like it were not individual authorly expressions, but rather the outcomes of discrete communities of practice. Literary creativity - the "making of books", as St Bonaventura famously put it (see Minnis 1984) - was therefore inevitably a negotiation, constrained by the contexts in which the various copies were produced. It is to these contexts - the "cultural maps" for each witness - that we will now turn.

\section{The manuscript witnesses}

2.1. Much recent research undertaken on medieval "miscellany" manuscripts (e.g., Martin 1981; Nichols \& Wenzel 1996; Connolly \& Radulescu 2015; Corbellini, Murano \& Signore 2018) has flagged that the correlation of individual text and 
individual codex is the exception rather than the rule in the production of books during the late medieval period across Europe. A cursory glance at the foliation for the witnesses for LFMB indicates immediately that this text was transmitted in exactly such ways, and part of its "mapping" requires some account of the textual company it keeps. Some of this company may be the outcome of random chance, triggered by what Ralph Hanna has called "exemplar poverty" (1996), but it is nevertheless worth noting any shaping that may be detected. These codicological patterns can sometimes be accounted for when placed alongside other data, such as indications of early provenance, or the evidence to be derived from dialectal analysis.

2.2. The A-version's somewhat curious appearance, as an abbreviated representative of the second version of LFMB, is a case in point. The manuscript in which A survives, dating from around 1480, is at first sight a collection of random texts, ranging from a group of comic poems such as the sole witness for The Hunting of the Hare (Scott-Macnab 2010) through didactic works and medical recipes to tail-rhyme romances. However, the manuscript's codicology has been the subject of detailed investigation by Philippa Hardman $(1978,2000)$ who has demonstrated convincingly that this "library in parvo" (Bennett 1947: 165) was in fact constructed according to logical editorial principles.

2.3. The manuscript containing the A-version of LFMB seems to have originally been a small collection of nine booklets that were subsequently bound together: soiling on the first and last leaves of each putative booklet is indicative of a period of time when the booklets had individual lives. Hardman has shown how three of these booklets, now Qs. 2, 4 and 5, were once a set of three separate but similar volumes, all written by one scribe, Richard Heege, and each one focused on a particular romance: Sir Gowther, Sir Ysumbras, and Sir Amadas respectively. Each romance, all of which survive in other witnesses, appears in a version which emphasises how the actions of the hero correspond to the operation of fortune's wheel; the compiler clearly had a taste for action-focused narratives. It seems that the original plan was that each romance should be followed by one further text: Stans Puer ad Mensam (sometimes known as Urbanitas), a courtesy-book on table-manners, was to accompany Sir Gowther, with LFMB (referred to as $D e$ Masse) beside Sir Ysumbras, and The Lyttel Childrens Book - another book on table-manners - alongside Sir Amadas. Scribal miscalculation with lineation in Q.4, containing Sir Ysumbras and LFMB, left some empty leaves which were subsequently filled with other material (differences in handwriting show that this material was added later, possibly a considerable time later). ${ }^{7}$

7 It may be interesting in this context to note that Richard Rolle's lyric "Loued be pou kyng", incorporated as we have seen in the B- and E-versions of LFMB, was in origin a meal-time grace (see Woolf 1968: 380). 
2.4. To modern eyes, equating LFMB with works on table-manners seems rather strange. However, Urbanitas derived ultimately from a Latin poem by the multitalented theologian Robert Grosseteste (d.1253), whose wide-ranging engagement with pastoral matters included - despite (or perhaps because of) his own humble origins - an interest in "courteous" behaviour. The abbreviated version of LFMB in the Heege manuscript, which focuses on initial preparation rather than on the canon itself, therefore becomes more explicable: there is after all - as might be perceived in the role of meals in morally-complex, late medieval English poems like Sir Gawain and the Green Knight - a parallel between courtly meal-times and the mass as a ceremonial meal of bread and wine. It is no coincidence that the word cortaysye, in Middle English, could appear in religious contexts (cf. the OED entry for courtesy, which includes citations from Ancrene Riwle and Richard Rolle's writings). LFMB's presence can be seen therefore not as a poem randomly included "for the unsophisticated worshipper" (TurvillePetre 1983: 139), but as part of a planned textual choice.

2.5. There is some evidence for the Heege manuscript's early provenance. Heege himself may have come from Derbyshire, possibly (as the library catalogue suggests) from the village of Heage in the east of the county, between Belper and Ripley. Other evidence of early provenance is a reference to Gibsmere in the neighbouring county of Nottinghamshire, in an account of expenditures included in Q.10, and the manuscript's post-reformation ownership by the Sherbrook family of Oxton, Nottinghamshire, which is half-way between Gibsmere and Heage. The Sherbrooks seem to have moved to Oxton in 1551 from Shirebrook in north-east Derbyshire. Major religious houses in the area included the Charterhouse at Beauvale, which is known to have owned English books; Neil Ker (1964: 9) notes that the house owned a book of saints' lives that is now Oxford, Bodleian Library, MS Douce 114. Welbeck Abbey, a Premonstratensian foundation just to the north of Shirebrook, owned a set of sermons partly in English, now Manchester, John Rylands, MS Lat. 179 (Ker 1964: 194; for the location and affiliation of both religious houses, see the Ordnance Survey's Monastic Britain, 1978, south sheet).

2.6. However, it seems likely that the Heege manuscript had humbler origins or readership than in a Charterhouse, or in a Premonstratensian abbey. As a later Sherbrook family-member reported to Robert Southey and Walter Scott, when they were negotiating the manuscript's purchase for the Advocates' Library in 1805-1806, the book was saved from "a parochial house at the reformation" (Hardman 1975: 246). One of the Sherbrook family, Cuthbert, who was later rector of Rockland, Norfolk, in 1537, owned many books, one of which - a gift from a fellow priest - was a major liturgical work, Guillaume Durand's Rationale divinorum officiorum, which discussed in detail the symbolism of the liturgy and 
the significance of ecclesiastical architecture. It is possible that such interests would have attracted Cuthbert to the LFMB, causing him to retrieve the book; however, the poem was not especially prominent with the collection, and perhaps not too much should be made of the parallel.

2.7. Locating the Heege manuscript, and specifically LFMB, on the Derbyshire/Nottinghamshire border is generally supported by an analysis of the poem's language - always bearing in mind that scribes were perfectly capable of moving about and taking their language with them (an important caveat: LALME's localisations are primarily typological rather than physical). ${ }^{8}$ A north-midland location is supported by the general appearance of $-s$ endings for the third-person present singular verb, combined with such forms as olde, holy with $\langle 0\rangle$ as the reflex of Old English $\bar{a}$, and this general localisation can be made more precise using the "fitting" tool available through the online revised version of LALME (see http://archive.ling.ed.ac.uk/ihd/elalme_scripts/mapping/fitting.html\#, last consulted 01/05/2020). According to LALME, the combination of such forms in A as gud 'good', kyrke 'church', mey 'may' (a rare form), mony 'man', seche 'such', peym 'them', po 'the', yitt 'yet' can easily be accommodated in Derbyshire.

2.8. One short Derbyshire document cited by LALME, viz. Nottingham, University Library, MS Mi.D.1908 (= LALME Linguistic Profile 105), indicates the kind of context of book-ownership in which the Heege manuscript might be placed, even though the Nottingham manuscript's language has been localised to the northwestern part of the county, in the Peak District, and dates from some fifty years earlier. The document, which contains such spellings as gude, kyrc, mey, is an indenture, "witnessing delivery by Hug' Wiloby kt. of a book called 'Portewos' to the vicar of Tideswell, the book to be kept in the choir of Tideswell Church" (http://archive.ling.ed.ac.uk/ihd/elalme_scripts/lib/display_lpZ.php?lpref=105, last consulted 01/05/2020). According to OED, a porteous (from Anglo-Norman porteose etc) was, in the fifteenth century, a portable breviary; it is perhaps significant that one of OED's citations, from a will dated to 1426 , is to "My masseboke, my portus" (cited from Furnivall 1882). The Willoughby family was prominent in the north-east midlands, later becoming the Barons Middleton, of Wollaton Hall to the west of Nottingham. The document is part of the Middleton

$8 \quad$ I have summarised this important point elsewhere: "The localization of texts by linguistic typological fit does not prove that texts were produced in the same place: a point which bears repetition, since linguistic evidence is sometimes referred to as proof of, rather than evidence for, provenance ... Scribes and authors moved about, and took their language with them; and to say that LALME places a text by linguistic means in such and such a location does not mean necessarily that the text was physically produced there" (Smith 2013a: 54; italics added). 
collection, which was passed to the university in 1947. Their cousins, the Chaworths of Wiverton in the south-east of the county, are known to have had an interest in books; Sir Thomas Chaworth's will, proved in 1458, included among other things "the best Mes boke", and "a litel Portose, the which the saide Sir Thomas toke with hym alway when he rode" (see Turville-Petre 1983: 132).

2.9. The B- and E-versions of LFMB are, as we have seen, the longest manifestations of LFMB. B seems to offer the oldest of all versions, in a manuscript copied at the end of the fourteenth century. LFMB is the first item in the book, and is followed by a pair of lyrics (also found in the Vernon Manuscript) and then, interestingly, by the religious poem Speculum Guy of Warwick. In this later work, Guy - a pious layman seeking religious instruction - is advised about various basic points of Christian belief by the (by this time) equally legendary figure of Alcuin, whose Liber de virtutibus et viciis (c. $800 \mathrm{CE}$ ) is a distant source. ${ }^{9}$ The remainder of the manuscript contains a miscellany of Latin and English works dealing with penitential issues, and ends with a prophecy of Antichrist and a collection of moral sentences.

2.10. The E-version survives in a composite manuscript, containing sections ranging from the thirteenth to the fifteenth centuries (James 1907: 79-82). Part II of the manuscript is a distinct booklet which seems to date from the early fifteenth century. LFMB is the first item in the booklet, followed by a macaronic lyric ("Saluator mundi domine"), a calendar of saints' feasts, and a version of the Proverbs of Solomon, a widely-circulated English didactic poem that famously appeared on the wall above a window at Grafton Manor, Worcestershire (see Boffey \& Edwards 2005: 210, item 3170, and references there cited). The remaining leaves of the booklet are filled in with notes on the calendar, and with various medical items, on urines and on blood-letting; the other booklets in the manuscript are all medicas, and Montague Rhodes James, the distinguished cataloguer, considered that one of the hands on the flyleaf was that of John Argentine (d.1508), the royal physician and provost of King's College, Cambridge (James 1907: 79).

2.11. Like the A-version, both $\mathrm{B}$ and $\mathrm{E}$ appear in manuscripts that can be localised by language to Derbyshire, in their cases by LALME. LALME did not map the E-version, but recorded that the language of all three hands in that manuscript "belongs to Derbys.". It may be significant that, according to James (1907: 79), two of the manuscript's flyleaves "are composed of an account roll

9 The original Liber was composed for Guido of Tours, whose name conveniently allowed him to be identified with the romance hero, "England's other Arthur"; see Edwards (2007). 
of a monastery in or near Derby dated 23 Hen. VI" (i.e., 1444); a possible candidate for the monastery is the Cluniac priory of St James. The collegiate church of All Saints at Derby, around 1527, contained ten "bokes in our Lady chapell tyed with chenes" (Ker 1964: 57). The B-version is for LALME a localisable text, LP 3, "placed" in north-east Derbyshire, near Mosborough (now a suburb of Sheffield, and since 1974 part of Yorkshire). Shirebrook is a few miles to the south. The manuscript containing the B-version was (according to an inscription on folio 3r) in the collection of John, Lord Lumley (c.15331609), and from there passed to the Royal collection. Before then the book seems, on the evidence of names written on several folios, to have travelled to East Anglia. The earliest external evidence of provenance is a fifteenth-century hand that records the name "Nich. Anger of Hiclilgham de parochia de Halys." "Hiclilgham" is generally interpreted as Heckingham, and the parish is that of Hales to the south-east of Norwich in Norfolk; the two villages have traditionally been linked within a single parish. ${ }^{10}$

2.12. The G-version of LFMB is the fifth text in its manuscript, beginning immediately after a prose work called the mawndy of oure lord; earlier texts in the book, a miscellany of religious prose and verse, include the Northern Passion, the Charter of Christ, and a prose Lamentation of Mary (the last later printed by Wynkyn de Worde). LFMB is followed by a series of works that, according to the provisions reaffirmed by Thoresby, formed a basic "kit" for religious instruction: reflections on the Ten Commandments, the Seven Deadly Sins etc., and vernacular versions of the Lord's Prayer, the Ave Maria, and the Apostles' Creed - these last elements, of course, found or referred to in other versions of LFMB. Indeed, the abbreviated prayer-focused form of the G-version of LFMB, noted already, seems to have been compensated for elsewhere in the manuscript; this second section of the book seems to have been envisaged as a whole set of prayers, consequent on the initial Easter narrative-sequence supplied by the Northern Passion.

2.13. The later parts of the manuscript containing $G$ contain longer religious materials, including a work on martyrdoms, a version of Erthe vpon Erthe (a short poem on mortality), The Abbey of the Holy Ghost, the life of "Saint" Edward the Confessor, meditations on the Eucharist (short selections from The Lay Folks' Catechism; see Boffey and Edwards 2005: 30, item 406.C), a version of Robert Mannyng's devotional poem of religious instruction, Handlyng Synne (cf. Boffey and Edwards 2005: 53, item 778), and writings ascribed to Richard Rolle.

10 Both places are graced by distinctive Norman round-tower churches, probably built by the same mason: see http://www.norfolkchurches.co.uk/hales/hales.htm, last consulted $02 / 05 / 2020$ 
An apparent exception to the religious theme is the metrical romance of Robert of Sicily, in a highly compressed form, but this poem regularly appears in other Middle English religious miscellanies as an exemplary narrative, demonstrating how pride leads to a fall while repentance leads to restoration; of the ten manuscripts containing the Middle English version of this romance, no fewer than eight place the poem alongside religious material (see Baker 1997: 166-167). It might be linked with Mannyng's poem, which contains various entertaining exempla. The book as a whole is thus a religious library in miniature; like the much larger Vernon Manuscript, it offers material for prayer and meditation, all focused on what the later Middle Ages called sowlehele (the apparent book-title for the Vernon Manuscript; see Smith 2020: 83, and references there cited).

2.14. As with the Heege manuscript, a Norfolk connexion can also be detected in this book. LALME localised the language of the manuscript to mid-Norfolk (= LP 621), and the scribe of the G-version of LFMB deploys some of the distinctive forms diagnostic of the area, e.g., $x a l$ 'shall', and - a feature common to Norfolk as well as northern Middle English - the use of $\langle y\rangle$ as the figura for thorn. It is interesting in this context to note that the last text in the manuscript ends (folio 197v) with the following colophon:

Here endith the informacon' of Richard the Ermite yt he wrote to an $n$ Ankyr translate oute of Northern' tunge in to Sutherne. that it schulde the bettir be vnderstondyn' of men' that be of the Selve Cuntre Amen'

It seems that the "Northern' tunge" (the presumed native idiom of "Richard the Ermite", i.e., Richard Rolle) - was seen as very distinct from, and indeed not necessarily mutually comprehensible with, "Sutherne" dialect.

2.15. Florence Foster, the editor of the Northern Passion for the Early English Text Society (1916), drew attention to ownership notes on folio $195 \mathrm{r}$ of the manuscript: "this is the boke of S Will. Trew In witnesses where for I thomas bareyle hauyng knowlage there off haue putt to myn signe". Other early inscriptions include "John Cuttyng worsted in comitatu", and "This is the boke ser Robt Hawe". Worstead is a village in eastern Norfolk, and Foster found the names Barrel, Cuttyng, Hawe, and Trew in various Norfolk parish records from the fifteenth and sixteenth centuries (1916: 13). The title ser 'sir' was commonly used in the later medieval period to refer to a priest, and priests with the names recorded in the manuscript are found throughout the region. Foster notes, for instance, that a Robert Hawe was Rector of Thetford (1473-1481). A Cambridge University Library binding record dated 25th November 1920, inside the front 
leaf, reads as follows: "From beneath the bookplate was removed a fragment of a document relating to Norwich and Sedgeford, circa 1300, now Doc. 799".

2.16. The remaining versions of LFMB, Simmons's "second group", might be taken together. The C-, D-, and H-versions all survive in manuscripts whose language has been "placed" by LALME. The C-version (= LP 7) was localised to the North Riding of Yorkshire, as indicated by spellings such as gude 'good', haly gaste 'Holy Ghost', ffra 'from', swilke 'such', sall 'shall', and the use of $\langle\mathrm{y}\rangle$ for thorn, and third-person present verbal inflexions in $-s$, including outside rhyming position, e.g., prayes 'prays', and has. The third-person plural pronouns are in characteristically northern form, i.e., thay 'they', yere 'their', $\operatorname{tham}(e)$ 'them'. LALME considered the language of the H-version (= LP 460) to be similarly from Yorkshire, albeit the West Riding, with even more markedly northern forms such as qwen 'when', es 'is'. The D-version, not assigned an LP number by LALME, is nevertheless recorded there as being written in a variety of northern Middle English, albeit otherwise "colourless"; again, northern forms may be noted such as buke 'book', werld 'world', ere 'are' etc.

2.17. The language of the I-version, which dates from the first half of the fifteenth century, is much less dialectally marked; its present-tense verbal inflexions (when not in rhyming position) generally indicate a south-east midland usage, e.g., treteth (third-person singular), passen (present plural), and this broad localisation of the language is supported by forms such as thei 'they' beside her 'their', hem 'them'. Sporadic northern -es in third-person present singular verbs, even in non-rhyming position, e.g., bigynnes, turnes, can be balanced against much more southerly beth 'are'. Sporadic forms such as mykel 'much' and ilka 'each' seem to carry-overs from an earlier northern exemplar, although they also occur further south, even in texts that can be localised on non-linguistic grounds to London; the forms whech 'which', hegh 'high', also found in the I-version are - though not found in the 'incipient standards' identified by Samuels (1963) as characteristic of late fourteenth-/early fifteenth-century London - not especially distinctive.

2.18. The language of the F-version is similarly colourless, though with - like that of the I-version - a generally south-midland character, with thei 'they', here 'their', hem 'them', and third-person present singular verbs (when not in rhyme) in -eth, e.g., asketh, folweth, techeth, cf. begynnes: synnes, where the verbal -es is clearly constrained by the necessity to retain the rhyme with the inflected noun; we might also note the line "Summen maketh here praierys", with a present plural in -eth. Possibly dialectally indicative are forms such as haw 'have', which according to LALME tend to cluster in eastern Norfolk, but in general regionalisms such as $3 u t$ 'yet', ham (beside more common hem 'them') are not 
especially dialectally distinctive; ham 'them' is found in varieties localisable to Norfolk, but also in Surrey and the west country, whereas $3 u t$ is found in many texts localised to the south and south-west. In sum, the F-version seems to contain the kind of language that was becoming increasingly common in the southern half of English, viz. "colourless" usage purged of diagnostically dialectal features but still deploying forms that were more generally "regional" rather than metropolitan, many of them spreading beyond their earlier origins.

2.19. The strongest evidence of provenance in the whole set of manuscripts under review appears in the $\mathrm{C}$-version. On folio $2 \mathrm{v}$ of the book, in a large formal textura hand, appears the following inscription:

\section{L iber beate Marie de Rieualle \\ ex procuracione domini Willelmi \\ Spenser. Abbatis eiusdem.}

The ex libris inscription "Liber ... Rievall[is]" is clear evidence that the manuscript was at the great Cistercian abbey of Rievaulx, in the North Riding of Yorkshire (Ker 1964: 149); William Spenser resigned as abbot in 1448. The inscription is repeated at the back of the book, on folio $274 \mathrm{v}$, but with beate and abbatis expanded. It is clear (although not explicitly stated by LALME's authors) that this inscription is the reason LALME used the manuscript as an "anchortext" for the early stages of their survey, subsequently "fitting" their other texts around them (for an account of the "fit"-technique adopted for LALME, see Benskin 1991).

2.20. The evidence for the provenance of the remaining manuscripts within this group is much less strong. There are no detectable marks indicating ownership in the D-version, which (according to Gerould 1904) is the closest textually to $\mathrm{C}$; it seems likely that any such indications were lost when the book was rebound in the eighteenth century. By contrast, there are several provenance marks in the manuscript containing the H-version, albeit none contemporary to the early fifteenth-century dating of the volume; the book was in the Gower family in the eighteenth century, after 1746 since the bookplate has the legend "Gower Earl Gower"; the earldom was conferred in that year. It was then confusingly bound with the (completely erroneous) legend "Gower's Poems" on the spine, no doubt accounting for the book's being long-ignored as containing a copy of LFMB. Similarly little is known about the provenance of the manuscript containing the I-version before it was bought by the British Museum (later Library) in the nineteenth century, from "J.-B. Inglis", presumably the inheritor from "C. Inglis, M.D.", whose bookplate is retained 
in the manuscript. The Newnham manuscript containing the F-version was once in the library of the collector (and Newnham benefactor) Henry YatesThompson (1838-1928), but again there are no earlier ownership marks, other than an intriguing eagle-emblem which appears in one or two places in the manuscript, albeit not in LFMB. ${ }^{11}$

2.21. More indicative of the "cultural maps" for these versions of LFMB are the accompanying texts in the manuscripts. The book containing the $\mathrm{C}$-version, as befits a major religious house like Rievaulx, is a substantial and carefullywritten volume containing Latin and English texts, the latter towards the end (see further Thomson 2011; see also Ker 1964: 159; Watson 1987: 58). The Latin writings include works ascribed to Robert Grosseteste, Innocent III, and Richard Rolle. LFMB is preceded by the Lay Folks' Catechism and was followed by The Abbey of the Holy Ghost. Other Middle English poems - interestingly, given the omissions already noted in the C-version of LFMB - include verses on the commandments, the Seven Deadly Sins, and vernacular versions of the Apostles' Creed and Ave Maria, the latter with what DIMEV refers to as a "wordtype acrostic" (https://www.dimev.net/Records.php?MSS=OxfCCC155, last consulted 06/05/2020). ${ }^{12}$

2.22. The manuscript containing the D-version is entirely devoted to vernacular religious verse in octosyllabic couplets, written by a single hand throughout. LFMB is prominently positioned at the very beginning of the book, followed by a short poem of prayer at the elevation, and then (folios 5v-167r) extensive selections from the Northern Homily Cycle, with versified gospel readings alternating with exemplary narratives. The last part of the book, occupying folios $167 \mathrm{r}-189 \mathrm{v}$, contains the Northern Passion. The book is clearly designed as a

11 On folio $1 \mathrm{r}$ of the Liverpool manuscript containing the H-version of LFMB is an interesting note in a $? 16^{\text {th }}$-century non-cursive script:

The mirrour of lyfe

1. Vox clamantis

2. Speculum meditantis \}

3. Confessio amantis \}

Iohan Gower//

The reference here is to the collection of major poems by John Gower, possibly a confusion because of the "Speculum" title of the first work in the manuscript, viz. the Speculum Vitae once ascribed to William of Nassington, which like the Confessio is written in rhyming couplets (see further Ker 1983: 309). The manuscript was purchased by Liverpool University in 1946.

12 The codex containing the C-version originally consisted of what are now three distinct manuscripts. Two portions of the book, other than the Corpus manuscript, are now London, British Library, MSS Cotton Vitellius D.v, folios 1r-16v, and Cotton Vespasian D.xiii, folios 181r-201v (see Ker 1964: 159; Watson 1987: 58). The former contains a Latin Constitutiones provinciales of York (i.e., canon law), while the latter contains The Abbey of the Holy Ghost. 
single enterprise, with the miracle of the mass at the beginning given its biblical foundation in the materials that follow. The F-version of LFMB, by contrast with $\mathrm{D}$ at least, seems to be a later addition, along with a short grace before supper. The bulk of the manuscript (folios 1r-104v) is occupied by a B-text of William Langland's alliterative poem Piers Plowman, in a distinct hand. ${ }^{13}$

2.23. Much more substantial is the manuscript containing the I-version of LFMB, another miscellany of vernacular poetry. The first item is Titus and Vespasian, or the Destruction of Jerusalem: a narrative surviving in several languages, including thirteen Middle English copies in rhyming couplets (as in this version), and a further nine alliterative renderings of a related story (usually referred to as the Sege of Ierusalem). The poem begins with a Crucifixion narrative, but then moves into legend. Vespasian, described as a king of Gascony, is also a leper suffering from the unusual complaint of wasps infesting his nose. Miraculously cured by Pope Clement, he refuses to be baptised until he, accompanied by his son Titus, travels to the Holy Land to avenge Christ's death; Jerusalem is destroyed. Vespasian subsequently becomes Emperor, and is christened. The remainder of the book turns to more conventional religious materials: a quatrain on Will and Wit, Richard Maidstone's version of the Seven Penitential Psalms, and finally LFMB. The combination of romance and religion is reminiscent of three of the booklets discerned in the Heege Manuscript.

\section{Mapping The Lay Folks' Mass Book}

3.1. Now that this body of information about the contexts of the various texts of LFMB has been assembled, how can it used to develop a "cultural map" for the poem, albeit very preliminary? In geographical terms, it seems clear that the work circulated in Derbyshire/Nottinghamshire, in Yorkshire, and in Norfolk, and can thus be related to other texts circulating in those areas. Some versions are likely to have emerged - they were certainly read - in parochial settings, possibly owned by local priests whose existence up to the Reformation might be exemplified, from a very different part of the country, by the life and career of the now well-known Exmoor priest Sir Christopher Trychay of Morebath (see Duffy 2001). There is also, as we have seen, evidence that the text could be deployed in monastic contexts; that is evidently the case with the codex containing the C-version, part of

13 See, for a discussion of the script, the Late Medieval Scribes resource, another project developed by Linne Mooney and a team of associates. The Newnham manuscript is discussed at https://www.medievalscribes.com/index.php?browse=manuscripts\&id=368\&nav=off, last consulted 06/05/2020. 
the Rievaulx library, though the mixture of Latin and English in that manuscript reminds us of the multilingualism of Cistercian existence, and indeed of the variety of religious experience for which such institutions catered.

3.2. Other collections may have been owned by pious gentry. We know, for instance, that devotional reading at meal-times was a family activity encouraged in the powerful Beauchamp circle:

Let the book be brought to the table as readily as the bread. And lest the tongue speak vain or hurtful things, let there be reading, now by one, now by another, and by your children as soon as they can read [...]. Expound something in the vernacular which may edify your wife and others (cited in Perry 2007: 156, and see references there cited; the document in which this passage occurs was probably written for John Throckmorton, head of council for Richard Beauchamp (1382-1489), Earl of Warwick).

Such behaviour was clearly possible in humbler households than Throckmorton's or Beauchamp's. When the suspected heretic Joan Baker was quoted, in the early sixteenth century, as saying that "she cold here a better sermond at home in hur howse than any doctor or prist colde make at Powlis crosse or any other place", she seems to be referring to a communal experience (cited in Hudson 1996: 132). Bishop Reginald Pecock (d. ca. 1459), who undertook a programme of vernacular composition to "counter the spread of heterodox ideas in Lollard books" (Oxford Dictionary of National Biography), saw the reading and rereading of such texts as permitting "the layman to memorize a fixed set of words which he could then repeat to others without distorting the information" (Spencer 1993: 41); Pecock himself refers - albeit as devotional practices less effective than the contemplation of images - to "the hearing of other men's reading, or .. hearing of his own reading", thus "assum[ing] the speaking of books" (Aston 1984: 114, and references there cited). We are reminded that the late medieval period saw the emergence not only of "literate cults" such as that of the Holy Name (Aveling 2016), but also of what Adam Fox (2000: passim) has referred to as a "literate environment", in which books were prototypically a resource for communal, often household reading; some would commonly listen, while others would read aloud. Memorisation of such texts is also known to have played a key role, encouraged by their presentation (like LFMB) in rhyming couplets (see Carruthers 1990).

3.3. More broadly, what emerges from a study of all the copies of the LFMB, and the contexts in which they existed, is that in most cases a shaping sensibility, if not always a shaping programme, may be observed. Ian Johnson, in an 
important theoretical essay on medieval miscellanies (2020 forthc.), has repurposed from other disciplines the notion of heterachy, citing such statements from other disciplines as follows:

from archaeology: "Heterarchy may be defined as the relation of elements to one another when they are unranked or when they possess the potential for being ranked in a number of different ways" (Crumley 1995: 3).

from economics: "[h]eterarchies are about distributed intelligence and the organization of diversity" (Stark 2001: 24).

As Johnson goes on to say (channeling Chaucer's famous line "Diverse men diversely hym tolde"):

Miscellanies may thus be seen as motivated and re-motivatable forms that preserve, transmit, and add cultural value, enhancing and reinvesting cultural capital by distributing diverse understanding diversely, and they are not unorganized in doing so (2020 forthc.).

A heterarchic collection is therefore designed typically for dipping into, for reading non-linearly, allowing users to detect connexions between texts. Such an approach recalls how, on a much larger and more sophisticated scale, the Bible was - and continues to be - read in portions within various offices, with passages from the Old Testament selected as prefigurations of the New. ${ }^{14}$

3.4. The relevance of this insight for the study of LFMB becomes clearer when placed alongside recent research into varieties of late medieval liturgical practice. Matthew Cheung Salisbury, for instance, has referred to "the absence of contemporary uniformity" in late medieval liturgy (2016: 93), noting that even

14 For a seminal account of the complex approaches the Middle Ages took to Biblical exegesis, see Smalley (1983), which focuses on the practices of religious orders and scholastic teachers. The practice in humbler circles is demonstrated by the so-called Biblia Pauperum, a Bible picture-book which circulated widely in Europe in the fifteenth century using woodcut printing. The Biblia Pauperum offers numerous illustrated examples of such prefigurations. One of the best-known examples was the story of Abraham's readiness to sacrifice his son Isaac (Genesis 22), often seen as prefiguring the Father's sacrifice of his Son Jesus at the crucifixion. Other examples commonly illustrated include the serpent's temptation of Eve (Genesis 3), seen as prefiguring Satan's temptation of Christ (Matthew 4). For an image of the latter from a Dutch Biblia Pauperum of ca. 1439-1460 (Glasgow, University Library, Sp Coll Hunterian Ds.2.4/10), see https://www.gla.ac.uk/myglasgow/library/files/special/ exhibns/treasures/bible.html, last consulted 17/06/2020 
the Sarum Use, the dominant pattern used in England for the Latin liturgy of the Mass, was a resource from which priests drew depending on circumstances rather than a template from which deviation was deplored (2016: 95; see also Pfaff 2009: 412-444); and Paul Barnwell has reminded us that, in the medieval liturgy, "experiences, particularly of the laity, were far from uniform" (2016: 209). Texts - both in Latin and in the vernacular - were malleable in form, open to reworking for a great variety of functions and situations.

3.5. Such a setting offers an appealing "distant mirror" to a twenty-first-century critical sensibility in which the authorial role in a text is balanced with - or even less important than - that of its audience. As Rosemary Woolf wrote of medieval English religious lyrics, "They give the impression that the author never looked at them with a satisfaction in poetic achievement, but fixed his [sic] mind on his subject-matter, and on the other on the ordinary layman who would use the poem" (1968: 15). The same conclusion may be applied to the LFMB, whose manuscripts were working volumes in which notions of authorship and audience were dynamic, and in which creativity was negotiated within a textuallytransmitted community of practice.

\section{Acknowledgements}

I am indebted, as ever, to my colleague David Jasper for ongoing discussion of LFMB, to Ian Johnson for early sight of his article on medieval miscellanies, and to two anonymous reviewers for SAP for their helpful comments on this article. David and I are also grateful to John Harper, for drawing our attention to the Experience of Worship project. Any remaining errors are my own responsibility.

\section{REFERENCES}

\section{PRIMARY SOURCES}

Baugh, Albert C. (ed.). 1956. The English text of the Ancrene Riwle, edited from British Museum MS. Royal 8.C.i. Early English Text Society

Blake, Norman (ed.). 1972. Middle English religious prose. Arnold.

Bülbring, Karl. 1905. Das Lay-Folks' Mass-Book in der Handschrift der Advocates Library in Edinburgh. Englische Studien 35. 29-33.

Foster, Florence (ed.). 1916. The Northern Passion. Early English Text Society.

Furnivall, Frederick (ed.). 1882. The fifty earliest English wills. Early English Text Society. 
Gerould, Gordon H. 1904. The Lay-Folks' Mass-Book from MS Gg V.31, Cambridge University Library. Englische Studien 33. 1-26.

Greig, Pamela. 2018. The Lay Folks' Catechism: An edition. Ph.D. dissertation, University of Nottingham.

Hanna, Ralph (ed.). 2007. Richard Rolle: Uncollected prose and verse. Early English Text Society. Hanna, Ralph (ed.). 2009. Speculum Vitae: A reading edition. Early English Text Society.

Hardman, Philippa (ed.). 2000. The Heege Manuscript: A facsimile of National Library of Scotland MS Advocates' 19.3.1. University of Leeds, School of English.

Littlehales, Henry (ed.). 1895-1897. The Prymer, or Lay-Folks' Prayer-Book. Early English Text Society.

Powell, Susan (ed.). 2009. John Mirk’s Festial. Early English Text Society.

Simmons, Thomas F. (ed.). 1879. The Lay Folks' Mass Book. Early English Text Society.

Simmons, Thomas F. \& Henry E. Nolloth (eds.). 1901. The Lay Folks' Catechism. Early English Text Society.

\section{SECONDARY SOURCES}

Aston, Margaret. 1984. Lollards and reformers: Images and literacy in late medieval religion Hambledon.

Aveling, Judith. 2016. The Holy Name of Jesus: A literate cult? In Sally Harper, Paul Barnwell \& Magnus Williamson (eds.), Late medieval liturgies enacted, Routledge. 191-204.

Baker, Joan 1997. Editing the Middle English romance Robert of Sicily: Theory, text, and method. Text 10. 161-179.

Barnwell, Paul S. 2016. The nature of late medieval worship: the mass. In Sally Harper, Paul Barnwell \& Magnus Williamson (eds.), Late medieval liturgies enacted, Routledge. 207-218.

Bennett, Henry S. 1947. Chaucer and fifteenth-century verse and prose. Clarendon Press

Benskin, Michael. 1991. The "fit"-technique explained. In Felicity Riddy (ed.), Regionalism in late medieval manuscripts and texts: Essays celebrating the publication of A Linguistic Atlas of Late Mediaeval English, Brewer. 9-26.

Bishop, Edmund. 1897. The origin of the Prymer. In Henry Littlehales (ed.), The Prymer, or LayFolks' Prayer-Book, Part II, Early English Text Society. xi-xxxviii.

Carruthers, Mary. 1990. The book of memory. Cambridge University Press.

Connolly, Margaret. 2003. Books for the "helpe of euery persoone pat penkip to be saued": Six devotional anthologies from fifteenth-century London. Yearbook of English Studies 33. 170-181. DOI: $10.2307 / 3509024$

Connolly, Margaret. 2011. Compiling the book. In Alexandra Gillespie \& Daniel Wakelin (eds.), The production of books in England 1350-1500, Cambridge University Press. 129-149.

Connolly, Margaret \& Linne Mooney (eds.). 2008. Design and distribution of late medieval manuscripts in England. Brewer.

Connolly Margaret, \& Raluca Radulescu (eds.). 2015. Insular books: Vernacular manuscript miscellanies in late medieval Britain. The British Academy.

Corbellini, Sabrina, Giovanna Murano \& Giacomo Signore (eds.). 2018. Collecting, organizing and transmitting knowledge: Miscellanies in late medieval Europe. Brepols.

Crumley, Carole L. 1995. Heterarchy and the analysis of complex societies. Archeological Papers of the American Anthropological Association 6(1). 1-5. DOI: 10.1525/ap3a.1995.6.1.1

Duffy, Eamon. 2001. The voices of Morebath. Reformation and rebellion in an English village. Yale University Press. 
Duffy, Eamon. 2005. The stripping of the altars. Traditional religion in England, 1400-1580. (2nd edn.) Yale University Press.

Duffy, Eamon. 2006. Marking the hours. English people and their prayers, 1240-1570. Yale University Press

Edwards, Anthony S. G. 2007. The Speculum Guy de Warwick and Lydgate's Guy of Warwick: The non-romance Middle English tradition. In Rosalind Field \& Alison Wiggins (eds.), Guy of Warwick: Icon and ancestor, Brewer. 81-93.

Fox, Adam. 2000. Oral and literate culture in England 1500-1700. Oxford University Press.

Garrison, Jennifer. 2017. Challenging communion: The Eucharist and Middle English literature. Ohio University Press.

Hanna, Ralph. 1996. Miscellaneity and vernacularity: conditions of literary production in late medieval England. In Stephen G. Nichols \& Siegfried Wenzel (eds.), The whole book: Cultural perspectives on the medieval miscellany, University of Michigan Press. $37-51$.

Hanna, Ralph. 2010. English manuscripts of Richard Rolle: A descriptive catalogue. Liverpool University Press.

Hardman, Philippa. 1975. A note on some 'lost' manuscripts. The Library s5-30(3). 245-247. DOI: 10.1093/library/s5-XXX.3.245

Hardman, Philippa. 1978. A mediaeval "library in parvo". Medium Avum 47(2). 262-273.

Harper, Sally, Paul Barnwell \& Magnus Williamson (eds.). 2016. Late medieval liturgies enacted. The experience of worship in cathedral and parish church. Routledge.

Hudson, Anne. 1985. A new look at The Lay Folks' Catechism. Viator 16. 243-258. DOI: 10.1484/J.VIATOR.2.301425

Hudson, Anne. 1996. "Springing cockel in our clene corn": Lollard preaching in England around 1400 In Scott L. Waugh \& Pieter Diehl (eds.), Christendom and its discontents. Exclusion, persecution, and rebellion, 1000-1500, Cambridge University Press. 132-147.

James, Montague R. 1907. A descriptive catalogue of the manuscripts in the Library of Gonville and Caius College. Cambridge University Press.

Jasper, David \& Jeremy J. Smith. 2019. The Lay Folks' Mass Book and Thomas Frederick Simmons: Medievalism and the Tractarians. Journal of Ecclesiastical History 70(4). 785-804. DOI: 10.1017/S002204691900054X

Johnson, Ian (forthcoming). 2020. Theorizing the miscellaneous and the Middle English Biblical paratext. In Denis Renevey, Marleen Cré \& Diana Denissen (eds.), Late medieval religiosity in England: The evidence of late fourteenth and fifteenth-century devotional compilations. Brepols.

Jolliffe, P.S. 1974. A check-list of Middle English prose writings of spiritual guidance. Pontifical Institute of Medieval Studies.

Ker, Neil R. 1964. Medieval libraries of Great Britain. Royal Historical Society.

Ker, Neil R. 1983. Medieval manuscripts in British libraries. Vol. III: Lampeter-Oxford. Clarendon Press.

LALME $=$ McIntosh, Angus, Michael L. Samuels \& Michael Benskin, with Margaret Laing \& Keith Williamson. 1986. A linguistic atlas of late mediaeval English. Aberdeen University Press.

Martin, C. Anthony. 1981. Middle English manuals of religious instruction. In Michael Benskin \& Michael L. Samuels (eds.), So meny people longages and tonges: Philological essays in Scots and mediaeval English presented to Angus McIntosh, Middle English Dialect Project. 283-298. 
Minnis, Alastair. 1984. Medieval theory of authorship. Scholastic literary attitudes in the later Middle Ages. University of Pennsylvania Press.

Nichols, Stephen G. \& Siegfried Wenzel (eds.). 1996. The whole book: Cultural perspectives on the medieval miscellany. University of Michigan Press.

NIMEV $=$ Boffey, Julia \& Anthony S. G. Edwards. 2005. A new index of Middle English verse. The British Library.

Ordnance Survey. 1978. Monastic Britain. Ordnance Survey.

Parkes, Malcolm B. 1992. Pause and effect: An introduction to the history of punctuation in the West. Scolar Press.

Perry, Ryan. 2007. The Clopton manuscript and the Beauchamp affinity: Patronage and reception issues in a West Midlands reading community. In Wendy Scase (ed.), Essays in manuscript geography. Vernacular manuscripts of the English West Midlands from the Conquest to the sixteenth century, Brepols. 131-159. DOI: 10.1484/M.TCNE-EB.3.2767

Pfaff, Richard W. 2009. The liturgy in Medieval England: A history. Cambridge University Press. DOI: $10.1017 / \mathrm{CBO} 9780511642340$

Powell, Susan. 1994. The transmission and circulation of The Lay Folks' Catechism. In Alastair Minnis (ed.), Late medieval religious texts and their transmission: Essays in honour of A .I. Doyle, Brewer. 67-84.

Powell, Susan. 1997. What Caxton did to the Festial. Journal of the Early Book Society 1. 48-77.

Raymo, Richard. 1986. Works of religious and philosophical instruction. In J. Burke Severs \& Albert E. Hartung (eds.), A manual of the writings in Middle English 1050-1500, VII, Connecticut Academy of Arts and Sciences. 2255-2378.

Salisbury, Matthew Cheung. 2016. Establishing a liturgical "text": Text for performance, performance as text. In Sally Harper, Paul Barnwell \& Magnus Williamson (eds.), Late medieval liturgies enacted, Routledge. 93-106.

Samuels, Michael L. 1963. Some applications of Middle English dialectology. English Studies 44. 81-94. DOI: 10.1080/00138386308597155

Scase, Wendy. 1992. Reginald Pecock, John Carpenter and John Colop's “common-profit" books: Aspects of book ownership and circulation in fifteenth-century London. Medium AEvum 61(2). 261-274. DOI: $10.2307 / 43629433$

Scase, Wendy (ed.). 2007. Essays in manuscript geography. Vernacular manuscripts of the English West Midlands from the Conquest to the sixteenth century. Brepols. DOI: 10.1484/M.TCNE-EB.6.09070802050003050106090500

Scott-Macnab, David. 2010. The Hunttyng of the Hare in the Heege manuscript. Anglia 128(1). 102-123. DOI: 10.1515/angl.2010.009

Smalley, Beryl. 1983. The Study of the Bible in the Middle Ages, third edition. Oxford: Blackwell

Smith, Jeremy J. 2013a. Mapping the language of the Vernon Manuscript. In Wendy Scase (ed.), The making of the Vernon Manuscript. The production and contexts of Oxford, Bodleian Library, MS Eng. poet. a. 1. Brepols. 49-70.

Smith, Jeremy J. 2013b. Punctuating Mirk's Festial: A Scottish text and its implications. In Martha Driver \& Veronica O'Mara (eds.), Preaching the word in manuscript and print in late medieval England: Essays in honour of Susan Powell, Brepols. 161-192.

Smith, Jeremy J. 2020. Transforming early English: The reinvention of early English and Older Scots. Cambridge University Press. DOI: 10.1017/9781108333474

Somerset, Fiona. 2013. Feeling like saints: Lollard writings after Wyclif. Cornell University Press. 
Spencer, H. Leith. 1993. English preaching in the Late Middle Ages. Clarendon Press. DOI: 10.1093/acprof:oso/9780198112037.001.0001

Stark, David. 2001. Heterarchy: Exploiting ambiguity and organizing diversity. Brazilian Journal of Political Economy 21(1). 21-39.

Thompson, John. 2008. The Middle English Prose Brut and the possibilities of cultural mapping. In Margaret Connolly \& Linne Mooney (eds.), Design and distribution of late medieval manuscripts in England, Brewer. 245-260.

Thomson, Rodney. 2011. A descriptive catalogue of the medieval manuscripts of Corpus Christi College, Oxford. Brewer.

Turville-Petre, Thorlac. 1983. Some medieval English manuscripts in the North-East Midlands. In Derek Pearsall, (ed.), Manuscripts and readers in fifteenth-century England, Brewer. 125-141.

Watson, Andrew G. 1987. Medieval libraries of Great Britain: Supplement. Royal Historical Society.

Woolf, Rosemary. 1968. English religious lyric in the Middle Ages. Clarendon. 